\title{
HIEROGLYPHS AND ARCHAEOLOGY AT COPAN
}

\author{
David Stuart \\ Department of Anthropology, Box 6050-B, Vanderbilt University, Nashville, TN 37235, USA
}

\begin{abstract}
The study of Copan's extensive hieroglyphic texts has grown hand in hand with long-term architectural excavations. Recent progress in Maya decipherment, much of it derived from work at Copan, now allows for new and potentially rewarding opportunities to integrate epigraphy and "dirt" archaeology. Toward this end, this paper provides an overview of the current knowledge of Copan's elite history, summarizing current knowledge of the ruler sequence and attributions of monuments and architecture to individual reigns. Thematic and stylistic changes are evident in the inscriptions between the Early and Late Classic periods, including a proliferation of subordinate elite texts in the decades leading up to political collapse. Also, new information is provided on the changing relations between Copan and Quirigua throughout the Classic period.
\end{abstract}

Copan, arguably the most intensely studied of Maya sites, has always been important to hieroglyphic decipherment. John Lloyd Stephens's first views of the inscribed stone monuments at the site led him to speculate on the historical nature of the inscriptions (Stephens 1841:I:137). A few decades later, Alfred P. Maudslay featured Copan in his seminal publication (18891902) of drawings and photographs - the standard source on monumental inscriptions used by early epigraphers such as Goodman (1897) and Seler $(1899,1900)$ to decipher calendrical notations in Classic period texts. Sylvanus G. Morley, the greatest field epigrapher of the next generation, produced as his first major work the Inscriptions at Copan (Morley 1920), which today remains the most exhaustive treatment of inscriptions from a single Maya center. During the 1980 s, epigraphic work at Copan became a collaborative effort, taking advantage of (and largely driving) the overall progress made in decipherment. Significantly, the epigraphic work of Goodman, Seler, Morley, and others was accompanied by more-or-less continuous excavations at the site (Fash 1991:47-62).

Naturally, archaeological investigations at Copan and elsewhere have matured greatly since initial exploration and documentation. Along with increasingly scientific excavation techniques, rapid progress in the decipherment of hieroglyphs now provides a compelling historical facet to the Maya archaeological record. Yet these rapid developments induce growing pains, mainly in the form of debates over methodology and the proper application of ancient texts to modern archaeological issues. The past several years have seen the emergence of a polemic within Mesoamerican archaeology over the role and limitations of hieroglyphic texts in archaeological interpretation. Some archaeologists posit that the propagandistic ancient texts have only very limited value for addressing broad anthropological issues or fundamental questions in archaeological interpretation (Webster 1989). In a related criticism, others see epigraphy as a largely uncritical discipline, where interpretations are shaped more by modern social and philosophical forces than by any rigorous methodology (Pendergast 1989). I contend that these views reflect the common ahistorical attitude that traditionally characterizes archaeological theory in North America (Trigger 1989a, 1989b:312-319). The opposite view in this debate regards textual material as the best source for reconstructing detailed historical episodes or narratives, even in the absence of any backing from the spotty archaeological record (Schele and Freidel 1990). Although I stress the importance of making good use of the historical record, I find myself agreeing with aspects of both viewpoints in the debate. Inscriptions certainly do have topical constraints (for example, economic records of the Maya are sadly lacking), and it would be more than naive to accept completely the contents of the inscriptions at face value. To compound the problem, the methodology behind recent decipherments has not yet been explicitly outlined (a deficiency I hope to address with work in progress). Understandably, therefore, the results of recent epigraphic research are apt to be viewed with considerable skepticism by those who have traditionally adopted nonhistorical methods for explaining the development of New World cultures.

At the same time, I feel that the results of decipherment, when they are rigorously tested and applied, are far from being fully employed in questions of broad anthropological or archaeological significance (Houston 1989). By noting what the ancient rulers chose or chose not to record in their histories, we may recognize how political and social concerns changed through time. The emic records left to us in the form of Classic inscriptions in no way provide objective history (if any such thing exists), and we should not expect them to. Rather, we are left with elite Maya civilization's own incomplete view of itself. Classicists have long recognized the obvious advantages of such subjective documents, for "it is the reading of inscriptions . . . which will provide the essential direct acquaintance, the 'feel' for ancient society, without which the formulation of precise historical questions or hypotheses is an empty exercise" (Millar 1983:82). As perhaps the most completely excavated site in the Maya area, and having the greatest number of well-preserved inscriptions, Copan offers a unique opportunity to re- 
late and evaluate the historical and ritual content of Maya inscriptions with other facets of the archaeological record. This paper summarizes aspects of recent studies on Copan's inscriptions, and assesses new decipherments in light of evidence from the excavations.

\section{THEMATIC TRENDS}

Ever since the breakthroughs of Proskouriakoff (1960, 1963, $1964)$ and Berlin $(1958,1968)$ came to be widely accepted, Classic period inscriptions have been viewed primarily as records of dynastic histories. But to use them for nothing beyond reconstructing name-and-date history is to underrate seriously their potential use in addressing questions that archaeologists and anthropologists often ask. In fact, hieroglyphic decipherments of the past five years at Copan reveal that dynastic history can sometimes play a secondary role in inscriptions. For example, the famous stelae of Copan's main plaza (most erected by the thirteenth ruler, Waxaklahun Ubah K'awil, otherwise known as 18 Rabbit) say virtually nothing of royal history. Rather, the emphasis is on the ritual dedications of the monuments themselves. Interestingly, each stela is named with its own hieroglyph. The rulers' names mostly appear as the "owners" of the stelae or "plant stones" as they were apparently called in Classic times. ${ }^{1}$ Such texts do not enable us to reconstruct much of the actual history of the Copan rulers' reigns.

The situation at Copan stands in contrast with the more personalized texts of other sites in the Late Classic period. The narrativelike inscriptions of Yaxchilan, for example, are replete with records of wars and ritual events (Mathews 1988). Many Maya sites probably had their own particular textual styles, reflecting the distinct emphases and concerns of rulers and scribes. Unfortunately, such subtle genres of inscriptions have received virtually no study, but may someday be important in attempts to formulate variations in Maya political and social organization.

If Copan's inscriptions from this period say so little of elite history, what, then, are the larger questions that they may help answer in conjunction with other archaeological data? We can begin to ascertain this by looking at changes in what topics the ancient scribes of Copan chose to record over time, and how they chose to record them. For example, throughout the Classic period, thematic changes can be traced within Copan's inscriptions. The limited historical content of the texts under Ruler 13. Waxaklahun Ubah K'awil, are even more pronounced in the Early and Middle Classic periods, when, not coincidentally, stelae portraits are extremely rare. But throughout the Late Classic and up to the cessation of monument dedication, changes in the other direction are also evident. With the construction of the great Hieroglyphic Stairway on Structure 10L-26, providing a long dynastic record and portraits of warrior-kings, a newfound sense of personalized history appears to be established, perhaps

${ }^{1}$ I first considered the "plant stone" or "tree stone" reading for the stela glyph in 1985, in the course of studying a royal title on Yaxchilan Stela 18 ("He of three plant stones") and uses of the term on stelae at Tonina and Copan. Linda Schele and I later proposed a phonetic reading of te' tun, "tree stone," although at present I have reason to doubt this transliteration. The te value for the plant element is based solely on the dangerous assumption that it represents a tree and thus means "tree." Significantly, this sign never substitutes for the well-known te element, T89. Some examples in other contexts suggest that it ends in the consonant $m$. in reaction to the defeat of Waxaklahun Ubah K'awil (Fash 1989; Fash and Stuart 1991; Miller 1989a). The texts of the last known king are mostly found in very private architectural settings, with no more mention of stela dedication rites. Now, at the end, the ruler seems to be the principal point of concern, not the monuments themselves. Before Copan's political collapse, we also see a drastic increase in the number of elite figures discussed in the inscriptions. These changes may well reflect, albeit indirectly, processes of political and cultural change that for years have been the focus of archaeology in the Copan valley.

These thematic shifts and trends, and their greater significance for archaeological interpretations, will be discussed in more detail below. To set the stage, an overview of the Copan texts, beginning with the earliest recorded dates and moving up through the Early, Middle, and Late Classic examples, will provide the necessary background for more general discussions of the evidence for political and social change.

\section{ALTAR Q AND COPAN'S BEGINNINGS}

Any detailed treatment of Copan's dynasty must begin with $\mathrm{Al}$ $\operatorname{tar} Q$, perhaps the most important inscribed stone from the site. Herbert Spinden's old interpretation of the 16 figures carved around the perimeter of the stone as an astronomical conference has long been refuted (Carlson 1977; Marcus 1976:141-145; Riese 1988). Following Stephens's (1841:I:141) precocious observations, it is now agreed that the figures and the name glyphs they are seated upon comprise a king list ending with the Late Classic ruler variously called Yax Pac, Madrugada, or New Sun at Horizon, who dedicated the monument at 9.17.5.3.4 (A.D. $775) .^{2}$ On the west face of the altar the sixteenth ruler faces the first, whom we now call K'inich Yax $K^{\prime} u k^{\prime} M o^{\prime}$ on the basis of a secure transliteration of his hieroglyphic name. Peter Mathews (personal communication 1983) and Berthold Riese (1984) noted that rulers mentioned in the inscriptions often carried so-called hel titles marking their numerical position in the sequence, and that these corresponded perfectly to the order of rulers on Al$\operatorname{tar}$ Q. Although the ruler sequence is "complete," difficulties persist in working out several details of the dynasty. Unfortunately, it has proved difficult to connect the names of early rulers on Altar Q with glyphs on the heavily fragmented monuments of Copan's Early Classic period. Many of Altar Q's name glyphs are apparently abbreviater or take an iconographic

\footnotetext{
${ }^{2}$ In this paper I will not use the common nicknames for the Copan rulers (18 Rabbit, Madrugada, etc.), but, rather, will refer to their numerical position in the known dynastic sequence (Ruler 11, Ruler 16, etc.). Although such designations seem impersonal, they provide several advantages. First, nicknames such as Mat Head or Smoke Shell usually describe the name glyphs, and are often far removed from any real translation of the name. The situation becomes problematic when the English nicknames are translated into Mayan, as in the case of Mat Head being called Popol Hol. In such cases, nonspecialists are likely to be misled in believing that the Mayan derives from transliteration of phonetic signs in the name glyph. Some names, such as Yax Pac, are approximations of the original name, yet employ wrong or incomplete readings (his true name probably began Yas Pasah ...., but this too is incomplete). For this ruler, then, I prefer the numerical designation, Ruler 16. Numerical designations offer the advantage of being similar to titles used by the Maya themselves ("the sixteenth successor"), and at Copan the ruler sequence depicted on Altar Q is solid. Where precise transliterations are possible, as in K'inich Yax K' $u k^{\prime}$ Mo' and Waxaklahun Ubah $K$ 'awil, the original Mayan name is preferable. In sum, we should avoid the use of "names" until we are very sure that we can actually read them.
} 
form that makes identification none too easy. To compound the problem, epigraphers working with Copan's inscriptions have had to confront the extremely ornate and playful character given to the glyphs throughout the Classic period. Even in later texts, personal names are very seldom written the same way twice (Figure 8), since they often employ complex sign substitutions and spellings that have only been worked out recently (see Lounsbury 1989 , for a discussion of the many variants of one ruler's name). The mundane character of the inscriptions' contents was more than balanced by their glorious visual display.

While Altar Q securely establishes the ruler sequence for the entire Classic period, several other texts hold tantalizing references to "predynastic" events and personages. The earliest date mentioned at Copan appears on Altar I', a tablelike monument located only a few meters south of Altar Q in the West Court of the main acropolis and dedicated by Ruler 12, or Smoke Imix God K (see later). From the date 9 Ahau $13 \mathrm{Cumku}$, a distance number of truly astounding length $(2.10 .16 .3 .0$, roughly 1,000 years!) counts forward to the period ending 9.12.10.0.0 9 Ahau 18 Zotz', the probable dedicatory date of the altar. The 9 Ahau 13 Cumku date (7.1.13.15.0 in the Long Count) is therefore a millennium earlier than Altar I'. This is one of the earliest quasi-historical dates ever mentioned in the Mesoamerican calendar system, corresponding to October 14, 321 B.C., in the Goodman-Martínez-Thompson correlation (584285). ${ }^{3}$ The earliest dated inscription from Mesoamerica is Stela 2 of Chiapa de Corzo, inscribed with the long count 7.16.3.2.13 (Coe 1976), nearly 300 years later than the date mentioned at Copan. What is the significance of Altar I's tantalizing date? No accompanying sentence describes its importance, so modern readers and archaeologists are left to speculate. Presumably, however, the significance of 7.1.13.15.0 9 Ahau 13 Cumku would have been obvious to any Classic-era Copaneco who could read this inscription - much like July 4, 1776, would be to most Americans. Possibly this ancient date represents some profound event in the mythical history of Copan.

Some 480 years later another important event is chronicled in the Copan inscriptions. Stela I and Stela 4, both Late Classic monuments located in the main plaza, make note of the period ending 8.6.0.0.0 (A.D. 159). Stela I goes on to mention another event 208 days later, on 8.6 .0 .10 .8 . The Stela I passage is particularly significant, for we find associated with it the hieroglyphic name of the earliest person, probably a ruler, that might actually have existed (Figure 1). Since no other historical information is known from the second or third centuries, we cannot secure his placement in any predynastic sequence of early rulers. We therefore might provisionally call him Ruler A.

The second, slightly later date mentioned on Stela I, 8.6.0.10.8, seems historically important, but unfortunately the associated glyphs are battered. Toward the end of this passage of the inscription, however, a bat glyph is discernible with the distinctive features of the Copan emblem glyph (Figure 2a). This is followed by what is called the sky-bone glyph, which has recently been associated with ancient Maya place names (Stuart and Houston 1991). It is reasonable to conclude that the Copan emblem main sign here represents the name of the locality. In other inscriptions, however, the name OxWitik (Three Witiks) is associated with Copan (Figure 2b). How the emblem glyph

${ }^{3}$ The Tablet of the Cross from Palenque records a mythical ruler associated with dates in the early sixth baktun, several hundred years before the date on Copan Altar I'.

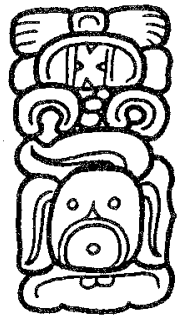

Figure 1. Name glyph of a "pre-dynastic" ruler who reigned in A.D. 159. Copan Stela I, D5a.

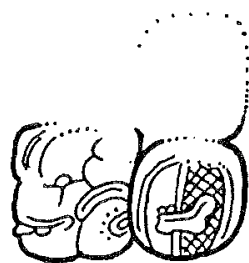

a

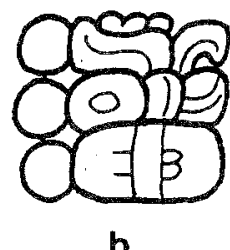

b

Figure 2. Place glyphs at Copan: (a) The bat emblem glyph as a place glyph, Copan Stela I, D9; (b) the place glyph for Ox Witik.

relates to the name Ox Witik is not clear. Nevertheless, the Stela I passage may discuss an important historical event involving the Copan site or polity during its formulation.

The significance of A.D. 159 in the epigraphic history is reiterated on Stela 4, a Late Classic monument located a short distance from Stela $I$ in the main plaza area of central Copan. The 8.6.0.0.0 period ending date occurs once again, but the associated glyphs are not as yet deciphered, and the name of Ruler A does not appear here. These early references to Copan become more intriguing when we realize that they fall in the late Preclassic period. At this time, Copan, unlike most major Maya centers of the southern lowlands, apparently suffered a drastic decline in population and ceremonialism (Fash 1983).

\section{THE EARLY CLASSIC}

Next we jump forward some 220 years to a date inscribed on the famous carved peccary skull from Tomb 1 (Longyear 1952:Figure 107o). The date is written 1 Ahau $8 \mathrm{Ch}^{3} \mathrm{en}$, which most likely corresponds to 8.17.0.0.0 (A.D. 376). On stylistic grounds, the skull may have been carved some years later, perhaps in the early katuns of baktun 9 . The small central scene of the peccary skull depicts two figures flanking a stela, accompanied by glyphs and a date that record the stela's dedication. A personal name, presumably that of a ruler, is the last glyph. We cannot assign this name to the roster of early Copan lords, however, for the 
skull is a portable object and nothing in its inscription points directly to a Copan provenance.

Another early monument to consider is Stela 24 (Fash and Stuart 1991:Figure 7.2). The small fragment that survives preserves essential historical information, including the initial series date 9.2.10.0.0 and, on the opposite side, the name of a mysterious figure who is called First in the Rulership. The name of the ruler, although eroded, is surely not that of K'inich Yax K'uk' Mo', who is named as the first ruler of Altar Q. To whom, then, do these glyphs refer? Unfortunately, the Stela 24 reference is unique, allowing us only to guess that the named ruler may be of a separate lineage. Stela 24 was found reused in the base of a later stela erected at the large site now occupied by the pueblo of Copan Ruinas. It is conceivable that this "twin" site in the Copan valley may have had its own distinct ruling lineage, although this supposition is speculative. Details of lineage and rulership at Copan are cloudy, since kinship ties between generations are seldom explicit. Parentage statements, for example, are very rare. It is important to remember that the sequence of rulers pictured on Altar Q are not designated as a single family line. This inherent ambiguity is relevant to discussions below.

Like Stela 24, most Copan monuments of the Early Classic period are fragmentary - so much so that no complete inscriptions were known before the recent discovery of Stela 63 . The vast majority of early stelae were apparently smashed for reuse in construction fill and in the foundations of later stelae. The fine preservation of sculpted detail and red paint on many pieces may indicate that some of the early inscriptions were displayed indoors, a pattern that might account for their destruction along with early architecture. Such interior placement of early stelae inside buildings is documented by the aforementioned intact Stela 63, found in the course of tunnel excavations in Structure 10L-26 (Fash and Stuart 1991; Fash et al. 1992). This stela was originally placed against the rear wall of a large two-chambered building, and was broken intentionally in the course of rebuilding some 200 years later. An inscribed step placed before the monument was severely damaged by burning. The general size and shape of Stela 63 are very similar to the fragmented early texts recovered from secondary contexts, which may originally have been placed in interior architectural settings also destroyed by later construction.

Stela 63 reports the baktun ending 9.0.0.0.0 8 Ahau $13 \mathrm{Ceh}$ (written $14 \mathrm{Ceh}$ ) in A.D. 435. The name of the first king from Altar Q, K'inich Yax K'uk' Mo', occurs in direct association with this date. Contrary to a previous interpretation (Fash and Stuart 1991:151), this date is not contemporaneous with the stone, since the inscription goes on to name a son of the first ruler, who apparently succeeded him as the second or third on the throne. However, we can be confident in dating the stela to the first few katuns in cycle 9.

As a near-contemporary reference to K'inich Yax K'uk' Mo', Stela 63 helps to resolve an issue that has vexed epigraphers and archaeologists working at Copan (Fash et al. 1992). In Late Classic texts, K'inich Yax K'uk' Mo' is linked with dates around 9.0.0.0.0. The inscription atop Altar Q (Figure 3) contains two such early events, one apparently referring to his "taking" of

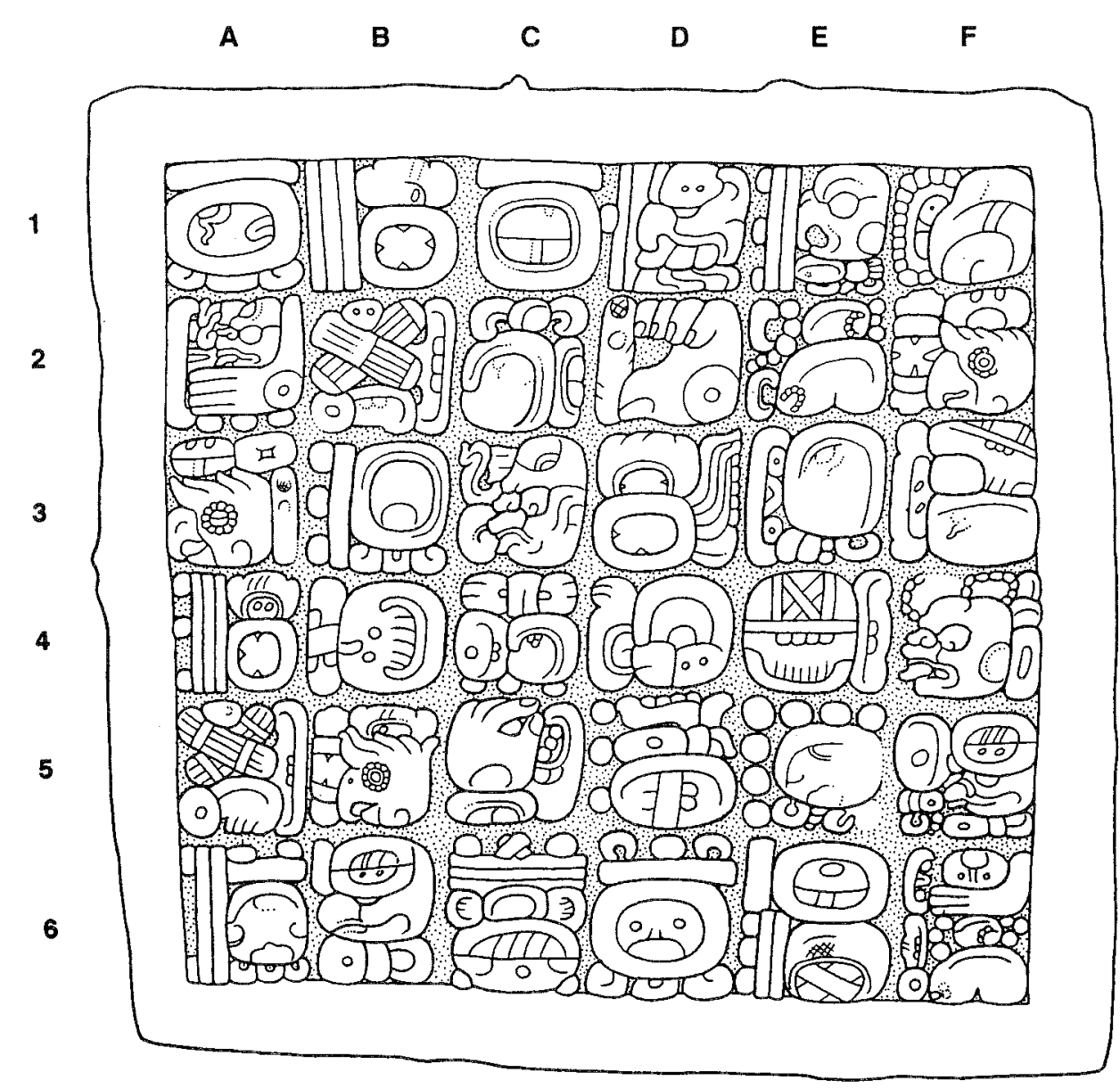

Figure 3. Inscription atop Copan Altar $\mathrm{Q}$. The glyphs in the first and second double columns record early historical events associated with K'inich Yax K' $u k^{\prime}$ $\mathrm{Mo}^{\prime}$. 
K'awil or God K (presumably a God K scepter) and another to his "coming" to Copan. The text goes on to mention the dedication of the altar early in the reign of the sixteenth ruler. Before the discovery of Stela 63 , it was difficult to ascertain whether the apparent importance of K'inich Yax K'uk' Mo' was little more than a glorification of the past by later rulers. Now, with inscribed monuments from the relevant time periods and an increasingly more detailed view of Early Classic archaeolog-

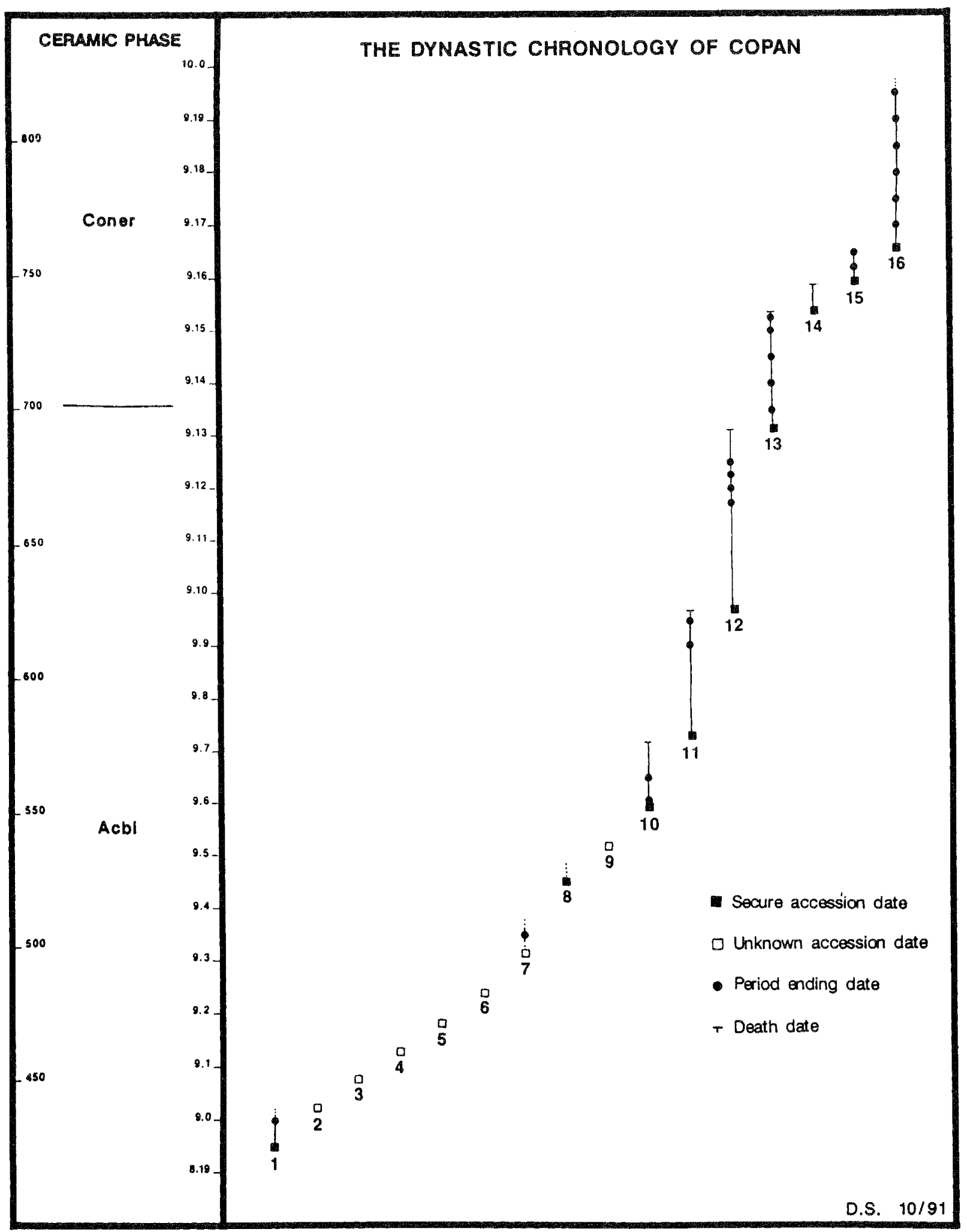

Figure 4. The dynastic chronology of Copan. 
ical remains in the acropolis, we begin to see that later Copan rulers were not inventing a brilliant tradition, but rather were continuing in it. Further excavations beneath the acropolis will provide more complete evidence of Copan's political and social setting during the years when K'inich Yax K'uk' Mo' is said to have reigned (see Fash et al. 1992, Sharer et al. 1992).

Schele (1990) notes possible references to the second and third Copan lords on Quirigua Monument 26, an Early Classic monument (see Fash et al. 1992). I hesitate to accept the identification of these names as Copan rulers, but the date of the stela would be appropriate for such references. ${ }^{4}$ In any event, Copan's early relationship with Quirigua does seem to have been important. As Stone (1983) has noted, the parallel passages from the texts of Copan's Altar Q and Quirigua's Zoomorph P discuss the early days of K'inich Yax K'uk' Mo's reign, perhaps demonstrating that historical connections between the sites were deeply rooted. Quirigua's dynastic relations with Copan is a complex and still unresolved issue, but this will be treated in more detail later.

Given the nature of the evidence discussed so far, our knowledge of Copan's early royalty is sketchy at best (Figure 4). Stela 63 names the second or third ruler, the son of K'inich Yax K'uk' Mo', but no other date can be associated with a ruler until we reach Ruler 7, sometimes called Waterlily Jaguar, who may have celebrated a period ending on 9.3.10.0.0, as recorded on Stela 15. In an attempt to fill in the large gaps in the Early Classic records, Nikolai Grube and Linda Schele (1988) have noted two possible examples of Ruler 4's name on the inscribed step found with Stela 63 and on another badly broken monument, Stela 53. In my view, the fragmented nature of these two texts and the illegibility of the surrounding glyphs force us to delay full acceptance of these identifications until future finds yield confirmation.

Stephen Houston (personal communication 1988) and Grube (1990) have also noted that an early Copan ruler is probably mentioned in an inscription from faraway Caracol, Belize. Caracol Stela 16, dated to 9.5.0.0.0 (Beetz and Satterthwaite 1981), names a Copan lord who may correspond to Ruler 8 or 9. Yet this identification is questionable given the problematic nature of the dates and name glyphs of many Copan rulers. ${ }^{5}$

\footnotetext{
${ }^{4} \mathrm{My}$ doubts about linking the Quirigua and Copan names rest mainly on visual evidence. Schele (1990) notes similarities between the name glyph of the so-called third successor on Quirigua, Monument 26, and the son of K'inich Yax K'uk' Mo' who is named on Copan, Stela 63 (the glyphs are compared in Fash et al. 1992). Both glyphs seem to be heads with mat symbols (hence the nickname Mat Head), but any similarities end there. The Copan name glyph shows a very distinctive $s$-shaped motif decorated with drilled dots and twisted elements, which Stephen Houston (personal communication 1991) suggests is related to Teotihuacan iconography, specifically spider imagery (see Taube 1983:Figures 3 and 12a). Whatever the motif represents, it is distinct from the mat on the Quirigua name. Houston (personal communication 1991) proposes that the Quirigua glyph may more likely be an early form of a dedication verb that is common in several Late Classic texts.

${ }^{5}$ Nikolai Grube (1990) prefers to see this as a reference to the seventh ruler, or "Waterlily Jaguar," discussed in previous chronological schemes worked out by Schele and myself (Schele and Stuart 1986; Schele 1989a). However, the dynastic chronology presented here contains some changes, especially in the dating of Rulers 7 and 8 . Ruler 7 is linked securely with 9.3 .10 .0 .0 , as recorded on Stela 15 . There is no reason to connect him with the 9.4.10.0.0 period ending on the same monument, however, as we had earlier considered. Indeed, the notation of a previous accession date on Stela 16 at 9.4.9.17.0 leads me to be-
}

This fascinating distant reference is nevertheless of potential importance for working out Copan's foreign relations during the Early Classic period.

In terms of the larger picture, chronology at Copan tells us that the reigns of nine Early Classic rulers must have been shortlived for the most part, collectively occupying no more than a 120-year span. This scenario contrasts with that of the Late Classic, which encompassed several lengthy reigns. This chronological pattern is visible in Figure 4 and is suggestive of changes in Copan's political structure from the Early to the Late Classic.

After the unattested reign of the ninth ruler, Ruler 10 (Schele 1986) left his mark with one important monument, Stela 9. Fortunately, A. P. Maudslay recorded this beautiful stone before its near total destruction at the hands of villagers who used it for building material in modern Copan Ruinas. However, Schele has recently recovered a number of the original fragments from Copan's many piles of sculpture, revealing that one side of the monument (surprisingly unrecorded by Maudslay) once bore a ruler's portrait. This is one of the rare images of a ruler from the Early Classic period. The text of Stela 9 provides its dedicatory date (9.6.10.0.0, or A.D. 564), as well as a statement that Ruler 10 was the child of Ruler 7 . Presumably the intervening rulers (also sons of Ruler 7?), like most of the Early Classic period, were enthroned for relatively short spans of time.

With the eleventh ruler in the Copan dynasty (also known as Buts' Chan) a more complete contemporaneous record of Copan's history emerges. The two monuments identified from his reign, Stelae 7 and $P$, seem to be the first Copan stelae left unscathed by subsequent demolition, probably pointing to some important political changes taking place during his reign (Fash 1983). Significantly, his monuments are spread over a wide area: Stela 7 was erected at the site of the modern village, while Stela $\mathrm{P}$ stood in the West Court of the main acropolis. The texts of these monuments are difficult to fathom, although the later Hieroglyphic Stairway provides some of the historical data concerning his rule: he acceded on 9.7.5.0.8 (A.D. 578) and died on 9.9.14.16.9 (A.D. 628). The particulars of Ruler 11's reign are elusive, because most of the relevant texts are unreadable. ${ }^{6}$ Contrary to one current theory (cited in Fash and Stuart 1991), however, it now seems doubtful that Ruler 11 ever incorporated

lieve that these are references to a succeeding ruler, probably Ruler 8 (although there is the off chance that it could also be Ruler 9). The problem in my revision, however, is Stela $E$, which Schele believes to be an early monument linking Ruler 7 with the dates 9.5.0.0.0 and 9.5.10.0.0. The style of Stela E indicates that it is a later monument, possibly dating from the reign of Ruler 12, who is named in its text. In any case, the inscription of Stela $E$ is largely unreadable, including, in my view, its initial series date. For the moment, therefore, the association of Ruler 7 with Stela $E$ or any date after 9.3 .10 .0 .0 is insecure.

${ }^{6}$ In saying that the texts are "unreadable," I should more precisely state that their meanings remain obscure, even if the constituent signs of the texts are recognizable or even phonetically transparent for the most part. The issue of the present ability to translate Maya texts usually results in various percentages, most of which I find far too high. Recently, Brown (1991) cites Schele's estimation that "at least $85 \%$ " of the inscriptions can now be "understood." Several problems arise in constructing such a figure, not the least of which is the definition of understand. For me, the ability to understand a text relies on precise phonetic transcription alongside reasonable caution in translating the meaning of ancient Mayan terms. If such a standard is used, I would generously estimate that only about $50 \%$ of the Classic period inscriptions are literally "readable." 
the distant site of Los Higos into the Copan hegemony. The questionable decipherments presented as evidence simply do not support this contention. Nonetheless, relations with other sites do appear in Copan's records (as was previously mentioned in connection with possible Copan references at early Quirigua). In the reign of the following ruler we see explicit evidence of Copan's broadening political horizons.

As Fash (1983) has noted, the explosion of inscribed monuments throughout the Copan valley during the reign of the twelfth ruler points to political expansion or consolidation during the early seventh century. Perhaps the most interesting monuments erected by this ruler are the well-known "outliers" - Stelae $10,11,12,13$ and 19 - placed at various locations in and around the valley, each stela in view of at least one of the others. All of these stelae appear to have been dedicated on 9.11.0.0.0 (A.D. 652). The many possible functions of these monuments have been discussed in the literature (Aveni 1980:240-245; Fash 1983; Morley 1920:133; Proskouriakoff 1973:171), although no particular interpretation seems more supported by the evidence than any other. Significantly, none of these inscribed monuments carry a portrait of Ruler 12 . The contrast becomes even more apparent when we realize that Stela 12's text is identical to that of Stela 2 from the site core, which was erected on the same period ending and, for some reason, depicts the ruler.

One of the more interesting aspects of Ruler 12 is the occurrence of his name on Altar L from Quirigua (Fash and Stuart 1991), attesting once again to the close ties that existed between Quirigua and Copan throughout the Classic period. The altar was carved at a time when Quirigua's ceremonial display was minimal, and it is reasonable to suppose that Copan politically dominated the region. Further evidence for this comes from a later text on Stela $E$ at Quirigua, which implies that the subsequent Copan ruler enthroned the then-subordinate Quirigua lord known as "Cauac Sky."

\section{THE LATE CLASSIC AND THE QUIRIGUA EPISODE}

With the accession of Waxaklahun Ubah K'awil, the ceremonial precinct of Copan begins to take its present form. The Great
Plaza is crowded with this ruler's highly ornate monuments, and hieroglyphic evidence allows us to assign various buildings in the acropolis to his reign. In every respect Waxaklahun Ubah K'awil continued the transformation of Copan launched by his immediate predecessor.

As noted above, the inscriptions of his reign are of limited interest historically, consisting of little more than dedicatory texts in the Great Plaza. One notable exception is the text in Structure 10L-22, once considered to be a much later building from the reign of Ruler 16, or Yax Pac (Miller 1988:170). From the text in the building and the style of carving, it now seems clear that this temple was dedicated in the reign of Waxaklahun Ubah K'awil, specifically on the 1 katun anniversary of his accession in A.D. 715. The inscription (Figure 5), recorded by Maudslay before it was destroyed by erosion, begins, "On 5 Lamat my katun was finished ..." As this date cannot be a period ending, it most likely records the anniversary on 9.14.3.6.8 5 Lamat 1 Zip. Note also that the above translation makes use of the first person. Only a few first-person texts are known from the Maya corpus, all others accompanying scenes on pottery vessels. Later we read, ". . y-al-ah-i, . . k'u, ... its'at" (. . He said it, .... the . . god, the . . . wise one). This patchy translation refers to the first-person speaker, possibly the ruler himself, making the text one of the most fascinating, if little understood, inscriptions in the entire Maya area.

Other buildings in the central area of Copan can be assigned to the reign of Waxaklahun Ubah K'awil. As Schele informs me (personal communication 1988), it may be no coincidence that the final ballcourt was built and dedicated on 9.15.6.8.13 (A.D. 738), months before the now-famous capture of Waxaklahun Ubah K'awil by the upstart Quirigua lord, Cauac Sky. Ritual ballcourts are now understood to be locales very much concerned with themes of warfare and captive sacrifice (Miller and Houston 1987). Schele speculates that the elderly Waxaklahun Ubah $\mathrm{K}$ 'awil may have formed a raiding party to inaugurate the new playing field, and had the tides reversed against him.

The sudden bellicose relations between Copan and Quirigua have been the focus of much of the previous epigraphic work at Copan. Proskouriakoff (1973:168) speculated on Quirigua's

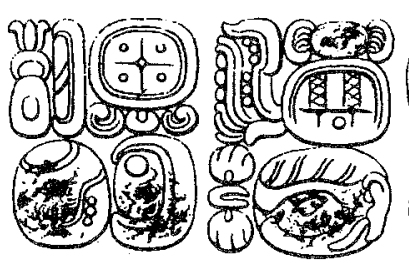

1

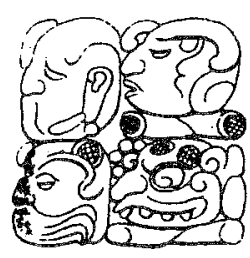

9

2

10
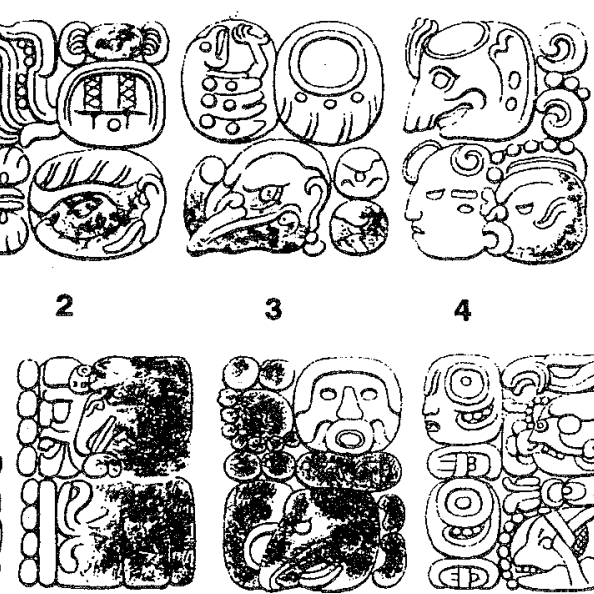

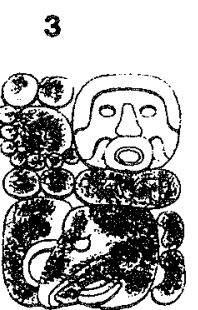

11
4

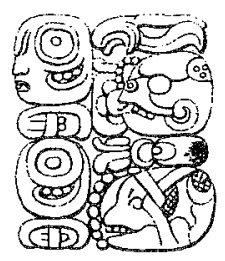

12
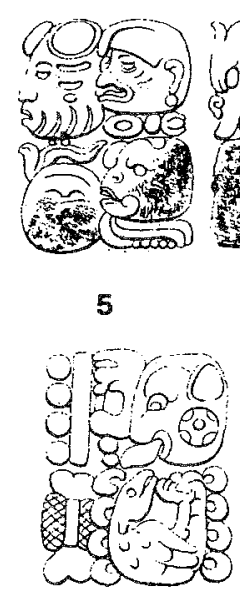

13

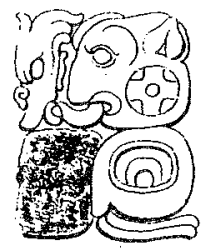

6

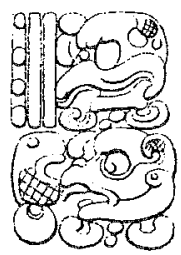

14

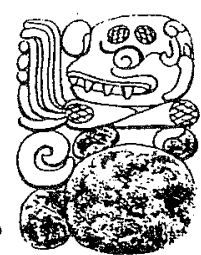

7

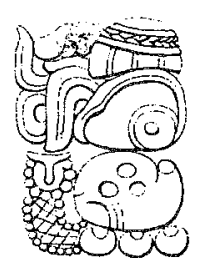

15

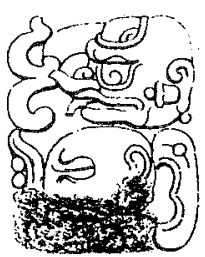

8

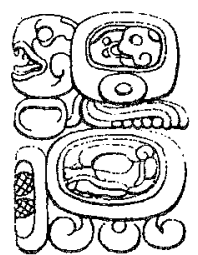

16

Figure 5. Inscription of Structure 10L-22 (now destroyed) as recorded by Annie Hunter (from Maudslay 1889-1902:Plate 16). The initial five glyph columns refer to Waxaklahun Ubah K'awil's first-person commemoration of his 20-year anniversary as ruler. 
"upper hand" in the event that took place on 9.15.6.4.16 $6 \mathrm{Cimi}$ 4 Tzec (A.D. 738), recorded many times in Quirigua's texts, and later Marcus (1976:135) specifically pointed to the apparent capture of the Copan ruler by Cauac Sky. Sharer (1978:17), also building on Proskouriakoff's observations, noted the apparent subsequent disruption of monument activity at Copan and Quirigua's concurrent rapid rise. Riese $(1986,1988)$ expanded the discussion by finding other epigraphic clues about the relationship between these two very important sites, most notably in the adoption of Copanec titles by the victorious Quirigua lord.

As a historical event, the capture of the elderly Waxaklahun Ubah K'awil remains understood only in the vaguest terms. The verb used to record the event is never the well-known capture glyph, but rather the so-called axe verb that most likely reads ch'ak, "to chop" (Orejel 1990), presumably referring to Waxaklahun Ubah K'awil's decapitation. Interestingly, the verb is written in reflexive voice, "he chopped himself," and, in at least one Quirigua inscription, the setting of the event appears to be a supernatural place. Self-decapitation is pictured on several mythological scenes on painted vessels from the Maya Lowlands. Evidently, the Quirigua ruler discussed the sacrifice within a mythological and supernatural context. Given the close ties between the sites that may date back to the Early Classic period, is it possible that Waxaklahun Ubah K'awil offered himself in sacrifice as cocelebrant of some ritual of mythical reenactment? Quirigua's texts indicate that such a possibility must be kept in mind. Whatever the precise nature of the event, however, indirect evidence from the archaeological and epigraphic record does suggest that the episode was bellicose, and had considerable social and political consequences at both sites. Sharer (1978) and Riese (1986) are surely correct in viewing the event as the launching point for Quirigua's Late Classic florescence. By contrast, Copan's inscriptions make little reference to the episode, and when they do it is in very different terms. Fragmented portions of the Hieroglyphic Stairway from Structure 10L-26 mention the date 6 Cimi 4 Tzec in association with war glyphs ( $u$ tok' $u$ pakal, "his flint, his shield"), ${ }^{7}$ and death. At Copan we never find the indelicate references to "chop," but rather more general accounts of Waxaklahun Ubah K'awil's demise.

In terms of monument construction at Copan, Riese (1986: 96-98, 101) sees the effects of the Waxaklahun Ubah K'awil's fall as being less profound than Sharer (1978) earlier claimed, noting that the Hieroglyphic Stairway, built some 20 years later, is the "equivalent of about 30 stelae of Copan size and quality." Nonetheless, I agree that Sharer's hiatus existed, since few if any monuments seem to have been built in the two decades after the event. It is noteworthy, for example, that the important katun ending 9.16.0.0.0 (A.D. 751) is absent from Copan's texts. Obviously, the Quirigua episode was highly disruptive, at least to judge from the monumental record.

One recently uncovered text may eventually shed some light on details of the Quirigua episode. Excavations by Wendy Ashmore and her team in Group $8 \mathrm{~L}-10$ uncovered portions of an

\footnotetext{
${ }^{7}$ The complete phonetic reading of the flint shield glyph was first worked out by Houston (1983), although its association with warfare was recognized long ago (Proskouriakoff 1973). Following Houston's decipherment, I have translated the glyph very literally, but it might very well be taken to be a compound noun like Nahuatl mitl chimalli (literally, "arrow-shield"), meaning "war, battle."
}

inscription that adorned the outer facade of Structure $8 \mathrm{~L}-74$ (Ashmore 1991). The data of the building's dedication is written as 7 Lamat 6 Tzec, falling just two days after Waxaklahun Ubah K'awil's death. The hieroglyphic name of the ruler was also found in the course of excavations. Although the text remains incomplete, future excavations in the group are sure to find the remaining blocks. It is hoped that missing portions will make reference, direct or indirect, to relations with Quirigua.

Although such discoveries may shed new light on Late Classic relations between Copan and Quirigua, revisions of earlier interpretations are also in order. Riese (1986:95-96), for instance, believes that the Quirigua ruler Cauac Sky adopted the Copan emblem glyph with his capture of Waxaklahun Ubah K'awil, and, furthermore, took another "Copan title glyph" to form Quirigua's own emblem. The first of these observations may be only partly correct. The Copan emblem glyph carried by Cauac Sky is different in one important respect: without exception it takes the color sign "black" ( $i k$ ') as a prefix. Thus, the Quirigua ruler is the "Black [Copan EG] Lord." The two titles are probably related (was Copan "blackened" by conquest, recalling the Aztec war metaphor atl-tlachinolli?), but it is not a simple case of title acquisition by the victor. Riese's second suggestion that the Quirigua emblem glyph is based on a Copan title is incorrect. As he himself notes (Riese 1986:96), "the prefixes of the Copan title glyph are partially changed, the kin infix is dropped, and the glyph itself is turned 90 degrees." The signs concerned are indeed different, and the supposed Copan "model" can be found in the inscriptions of many other sites, including Quirigua itself (Stela E; D20), in identical form. Riese (1986:98) also points to a possible Quirigua emblem glyph on the Hieroglyphic Stairway of Copan's Structure 10L-26. This too seems problematic, given the unique affixed signs and our present inability to read any surrounding glyphs that might hold a personal name.

What are we to make of these revised interpretations, minor though they seem? First of all, the notion that Cauac Sky saw himself as a usurper of Copan's rulership may be overstated. Title acquisition through capture has never been documented in the inscriptions of other sites. Yet Riese may be correct when he notes that Cauac Sky, calling himself the 14th Successor, saw himself as the direct successor in Copan's ruling line. Some twenty years after the capture, Copan begins anew its monument construction, and also claims to have its own numbered successors of Waxaklahun Ubah K'awil. But are we necessarily witnessing two conflicting histories, where Copan remained "unimpressed with (Quirigua's) audacious claim" (Riese 1986:98)? I am reluctant to say so, since we know precious little of Classic Maya concepts of Classic Maya political "rights," if we may call them that. To say someone is a " $n$th successor" does not presuppose an exclusive claim to the title; given their earlier intimacies, both Copan and Quirigua in the Late Classic period may have represented two branches of rulership, having a common origin in Waxaklahun Ubah $\mathrm{K}$ 'awil. If this is true, the historical relationship between the two sites would be closer than previously believed, and any study of one site would demand a deep knowledge of the inscriptions of the other.

Clearly, the nature of the relationship between Quirigua and Copan requires much more study. One of the weak points in our knowledge is the textual record of Quirigua, which, surprisingly, has never been adequately documented. The drawings published 
by Maudslay remain the only source for most of the lengthy inscriptions; modern attempts to render other Quirigua inscriptions have met with mixed results (Jones 1983). Several of the poorly known texts mention Copan and Waxaklahun Ubah K'awil, but only on-site investigations of the glyphs can tell us more.

To summarize, a 20-year gap in Copan's monument construction follows the Quirigua episode. Some sort of political disruption took place, even if it did not entail a permanent demise of the Copan polity. Unfortunately, the inscriptions of Quirigua and Copan, although they seem to discuss the event in different terms, are altogether silent on the precise nature of their conflict, and any ensuing sociopolitical or economic effects would be difficult to document without additional information. Here, then, lie the limitations of the documentary record. As yet, no archaeological evidence apart from the inscriptions would suggest a "war" between Quirigua and Copan, and the texts go no further in providing direct reference to cause and effect. Like most "wars" mentioned in Maya texts, we shall probably never understand the Quirigua episode in much historical detail. Should we then bemoan such limitations of the textual data? I think not. Rather, as I shall discuss, later sociopolitical consequences at Copan may be discernible by using more indirect evidence for the inscriptions.

Ruler 14, the successor of Waxaklahun Ubah K'awil, is a curious figure in Copan's history. The Hieroglyphic Stairway and Stela $\mathrm{N}$ tell us that he succeeded 19 days after his predecessor's death, but these are not contemporaneous accounts. Since no monuments or buildings can be securely assigned to his short reign, all that we know of him comes from the records of later rulers. The only construction that might be assigned to Ruler 14 's reign is Structure 10L-22A, adjoining 10L-22, built by Waxaklahun Ubah K'awil. This is suggested only by several large 9 Ahau glyphs (combined with the sign for nah, "house"), which adorned the exterior of the building. If we assume that these refer to a period-ending date, 9.15.15.0.0 9 Ahau $18 \mathrm{Xul}$ seems a likely possibility. However, there is considerable room for other interpretations of the 9 Ahau glyphs. Recently, it was suggested that Structure 10L-22A functioned as a community house (called popol nah in Yucatec, or popol otot in Chorti), on the basis of the large mat ( $p o p$ ) motifs that decorated its outer facade (Fash et al. 1992). If the date is correct, as Fash et al. speculate, then the construction of the community house some nine years after the Quirigua episode may have reflected an effort to reconstitute Copan's disrupted political system. It is important to remember, however, that such a historical interpretation of the events largely depends on our speculative chronological placement of the 9 Ahau reference.

Many scholars have recognized that the reign of the Ruler 15 (Smoke Shell) saw a renaissance in sculptural dedication and architectural construction at Copan. Foremost among his monuments is Structure 10L-26 and its Hieroglyphic Stairway. The inscription on the stairway, badly fragmented as it is, provides our most important source on the dynastic history of Copan. Whereas Altar Q first allowed us to identify the sequence of 16 rulers, the stairway fills in most of the essential chronological and historical details. One of the major goals of the recent work in the acropolis of Copan has been the refitting of the tumbled portions of the stairway (about two-thirds of the inscription were reconstructed out of their original sequence). Because of the sorry preservation of many of the blocks, we have achieved only limited success in the endeavor (Stuart and Schele 1986). The few fits made permit the reconstruction of previously unknown accession dates for a few of the rulers. Moreover, as the inscription has been gradually and expertly documented by Barbara Fash, we have been able to glean a number of other interesting facts about the stairway itself. The dedication date of the stairway took place on 9.16.4.1.0 (A.D. 755), some seven years after the accession of Ruler 15 . References are also made to dedications of earlier stairways, perhaps those corresponding to earlier phases of Structure 10L-26 (see Fash et al. 1992). The situation illustrates well the use of hieroglyphic data in questions of stratigraphic interpretation.

Ruler 15 was the last to erect stelae in the plaza areas of Copan. Stelae M (A.D. 756) and N (A.D. 761) date to his reign, the latter now assigned to Ruler 15 from an erroneous attribution to Ruler 16 (see, e.g., Baudez 1988:130). The presence of a rising sun glyph on its text led to the previous assignment of Stela $\mathrm{N}$ to Ruler 16, but this glyph is instead part of the stela's proper name; Ruler 15 is named later in the same inscription. Since the monument's dedication date, 9.16.10.0.0 (A.D. 761), falls two years before Ruler 16's accession, the reassignment frees us from explaining why a stela would be dedicated by a ruler to be. Moreover, the placement of Stela $\mathrm{N}$ in front of Structure 10L11 , traditionally assigned to Ruler 16 , might be explained by the fact that only the superstructure seems to be so late, with the substructure probably built during Ruler 15 's reign, if not earlier. This later construction, revealed by exploratory excavations in 1987, coupled with the death-related iconography and tantalizing shaft inside Structure 10L-11, suggest that Ruler 15's tomb may lie undisturbed behind the present location of Stela $\mathrm{N}$, his last monument.

\section{RULER 16 AND THE EXPANSION OF THE NOBILITY}

As recent archaeological and epigraphic research demonstrates (Fash 1983; Riese 1989; Sanders 1989; Willey and Leventhal 1979), evidence of Copan's political structure is by no means restricted to the architectural and sculptural monuments of the main acropolis. On the contrary, our knowledge of the administrative infrastructure below the supreme ruler, or $k^{\prime} u l$ ahaw (holy lord), is best revealed by looking at the rich settlement remains outside the site core. The excavation of so-called Type IV groups (Willey and Leventhal 1979) in the Copan valley during various phases of the project have revealed several important inscriptions that tell us something of the relationships between the later Copan rulers and their subordinates. Several nobles' names occur prominently during the reigns of the last two rulers, and two of these figures deserve more detailed comment.

During the later reign of Ruler 16, the name of one noble appears often in the texts of Copan. His name glyph is not completely readable, although he is sometimes referred to in the literature as Yahaw Chan Ah Bac (an incomplete and partially erroneous transliteration of the name glyph; see Table 1). Avoiding the inevitably troublesome use of nicknames and problematic decipherments, I prefer to use the unexciting label Personage A. He figures prominently in the texts of Altars T and $\mathrm{U}$, discovered at the largely destroyed site beneath the modern village. His name also appears on the battered remains of an inscribed incensario lid that was recently discovered on the 
Table 1. Copan rulers: A chronology

\begin{tabular}{|c|c|c|c|c|c|c|c|}
\hline Date & & Monument & Event* & & Date & Monument & Event* \\
\hline \multicolumn{4}{|c|}{ K'inich Yax K'uk' Mo' } & \multicolumn{4}{|c|}{ (Waxaklahun Ubah K'awil, continued) } \\
\hline $8 \cdot 19.10 .10 .17$ & 5 Caban 15 Yaxkin & Altar Q & $\mathrm{AC}$ & 9.14 .0 .0 .0 & 6 Ahau 13 Muan & St. C & DD \\
\hline 8.19 .10 .11 .0 & 8 Ahau 18 Yaxkin & Altar Q & "He came" & 9.14 .3 .6 .8 & 5 Lamat 1 Zip & $10 \mathrm{~L}-22$ & DD \\
\hline 9.0 .0 .0 .0 & 8 Ahau 13 Ceh & St. 15,63 & $\mathrm{PE}$ & 9.14 .10 .0 .0 & 5 Ahau 3 Mac & St. $F$ & $\mathrm{DD}$ \\
\hline \multirow{3}{*}{\multicolumn{4}{|c|}{$\begin{array}{l}\text { Ruler 2-Ruler } 6 \\
\text { No dates }\end{array}$}} & 9.14 .15 .0 .0 & 11 Ahau $18 \mathrm{Zac}$ & St. 4 & $\mathrm{DD}$ \\
\hline & & & & 9.14 .19 .5 .0 & 4 Ahau 18 Muan & St. $\mathbf{H}$ & $\mathrm{DD}$ \\
\hline & & & & 9.15 .0 .0 .0 & 4 Ahau 13 Yax & St. B; Altar S & $\mathrm{DD}$ \\
\hline \multirow{2}{*}{\multicolumn{4}{|c|}{$\begin{array}{l}\text { Ruler } 7 \\
\text { 9. } 3.10 .0 .0 \quad 1 \text { Ahau } 8 \mathrm{Mac}\end{array}$}} & 9.15 .5 .0 .0 & 10 Ahau 8 Ceh & St. D & $\mathrm{DD}$ \\
\hline & & 10L-26, HS & $\mathrm{PE}$ & $9.15 \cdot 6.8 .13$ & 10 Ben 16 Kayab & Ballcourt & $\mathrm{DD}$ \\
\hline \multirow{2}{*}{\multicolumn{4}{|c|}{ Ruler 8}} & 9.15 .6 .14 .6 & 6 Cimi 4 Tzec & 10L-26, HS & $\mathrm{DE}$ \\
\hline & 5 Ahau 8 Yaxkin & St. 16 & $\mathrm{AC}$ ? & $9.15 \cdot 6.14 .7$ & 8 Lamat 6 Tzec & $8 \mathrm{~L}-74$ & $\mathrm{DD}$ \\
\hline \multicolumn{4}{|c|}{$\begin{array}{l}\text { Ruler } 9 \\
\text { No dates }\end{array}$} & $\begin{array}{l}\text { Ruler } 14 \\
9.15 .6 .16 .5 \\
9.15 .15 .0 .0\end{array}$ & $\begin{array}{l}6 \text { Chicchan } 18 \text { Kayab } \\
9 \text { Ahau } 13 \text { Xul?? }\end{array}$ & $\begin{array}{l}10 \mathrm{~L}-26 ; \text { St. N } \\
10 \mathrm{~L}-22 \mathrm{~A}\end{array}$ & $\begin{array}{l}\mathrm{AC} \\
\mathrm{DD} ?\end{array}$ \\
\hline \multicolumn{4}{|l|}{ Ruler 10} & 9.15 .17 .12 .16 & 10 Cib 4 Uayeb & $10 \mathrm{~L}-26, \mathrm{HS}$ & $\mathrm{DE} ?$ \\
\hline 9. 5.19. 3. 0 & 8 Ahau $3 \mathrm{Mac}$ & 10L-26, HS & $\mathrm{AC}$ & Ruler 15 & & & \\
\hline 9.6 .0 .0 .0 & 9 Ahau 3 Uayeb? & St. 17 & $\mathrm{DD}$ & 9.15 .17 .13 .10 & 11 Oc 13 Pop & 10L-26; St. N & $\mathrm{AC}$ \\
\hline 9. 6.10 .0 .0 & 8 Ahau $13 \mathrm{Pax}$ & St. 9 & $\mathrm{DD}$ & 9.16 .4 .1 .0 & 6 Ahau 13 Tzec & $10 \mathrm{~L}-26$, HS & $\mathrm{DD}$ \\
\hline 9.7 .4 .17 .4 & 10 Kan 2 Ceh & 10L-26, HS & $\mathrm{DE}$ & 9.16 .5 .0 .0 & 8 Ahau 8 Zotz & St. M & DD \\
\hline \multicolumn{4}{|l|}{ Ruler 11} & 9.16 .10 .0 .0 & 1 Ahau 3 Zip & St. N & DD \\
\hline 9.7. 5. 0.8 & 8 Lamat 6 Mac & $10 \mathrm{~L}-26, \mathrm{HS}$ & $\mathrm{AC}$ & Ruler 16 & & & \\
\hline 9. 9. 0.0.0 & 3 Ahau 3 Zotz & St. 7 & $\mathrm{DD}$ & 9.16 .12 .5 .17 & 6 Caban $10 \mathrm{Mol}$ & $10 \mathrm{~L}-11$ & $\mathrm{AC}$ \\
\hline 9. 9.10 .0 .0 & 1 Ahau 13 Pop & St. $\mathrm{P}$ & DD & $9.16 .18 \cdot 2.12$ & $8 \mathrm{~Eb} 5 \mathrm{Zip}$ & 10L-11 Rev. Stand & $\mathrm{DD}$ \\
\hline 9. 9.14.16. 9 & 3 Muluc 2 Kayab & 10L-26, HS & $\mathrm{DE}$ & $?$ & & $10 \mathrm{~L}-21 \mathrm{~A}$ & DD \\
\hline \multicolumn{4}{|l|}{ Ruler 12} & 9.17 .0 .0 .0 & 13 Ahau 18 Cumku & $10 \mathrm{~L}-11$ & $\mathrm{DD}$ \\
\hline 9.9.14.17. 5 & 6 Chicchan 18 Kayab & 10L-26, HS & $\mathrm{AC}$ & 9.17 .1 .0 .0 & 9 Ahau 13 Cumku & incensario & DD \\
\hline 9.11 .15 .0 .0 & 4 Ahau $13 \mathrm{Mol}$ & St. 5 & $\begin{array}{l}\mathrm{AC} \\
\mathrm{DD}\end{array}$ & 9.17 .2 .12 .16 & $1 \mathrm{Cib} 19 \mathrm{Ceh}$ & $10 \mathrm{~L}-11$ & $\mathrm{DD}$ \\
\hline 9.12 .0 .0 .0 & 12 Ahau $8 \mathrm{Ceh}$ & St. $2 ; 10 ; 12 ; 13 ; 19$ & $\begin{array}{l}\mathrm{DD} \\
\mathrm{DD}\end{array}$ & 9.17 .3 .12 .0 & 11 Ahau 3 Ceh? & $9 \mathrm{~N}-82$ & $\mathrm{DD}$ \\
\hline 9.12 .5 .0 .0 & 3 Ahau $3 \mathrm{Xul}$ & altar of St. 1 & DD & 9.17 .5 .3 .4 & $5 \mathrm{Kan} 12 \mathrm{Uo}$ & Altar Q & $\mathrm{DD}$ \\
\hline 9.12 .10 .0 .0 & 9 Ahau 13 Zotz & St. 6 & $\mathrm{DD}$ & 9.17 .10 .0 .0 & 12 Ahau 8 Pax & $9 M-18$ & BL \\
\hline \multirow{2}{*}{\multicolumn{2}{|c|}{ 9.13. 3. 5. 7 12 Manik 0 Yaxkin }} & $9 \mathrm{~N}-82, \mathrm{HS}$ & DE & 9.17 .12 .5 .17 & 4 Caban 12 Zip & $22 \mathrm{~A}$ stone & AN \\
\hline & & & & 9.18 .5 .0 .0 & 4 Ahau 13 Ceh & 22A stone: Altar $\mathrm{G} 2$ & DD \\
\hline \multicolumn{4}{|c|}{ Waxaklahun Ubah K'awil } & 9.18 .10 .0 .0 & 10 Ahau $8 \mathrm{Zac}$ & Altar G3 & $\mathrm{DD}$ \\
\hline 9.13 .3 .6 .8 & 7 Lamat $1 \mathrm{Mol}$ & St. J; 10L-26, HS & $\mathrm{AC}$ & 9.18 .10 .17 .18 & 4 Etznab $1 \mathrm{Zac}$ & $10 \mathrm{~L}-18$ & $\mathrm{DD} ?$ \\
\hline 9.13 .10 .0 .0 & 7 Ahau 3 Cumku & St. $\mathrm{J}$ & DD & 9.18 .12 .5 .17 & 2 Caban $15 \mathrm{Pax}$ & incensario & AN \\
\hline 9.13 .16 .6 .8 & 7 Lamat 16 Zotz & incensario & AN & 9.19 .0 .0 .0 & 9 Ahau $18 \mathrm{Mol}$ & Quirigua Str. 1 & BL \\
\hline 9.13 .18 .17 .9 & 12 Muluc 7 Muan & $10 \mathrm{~L}-26-2 \mathrm{nd}$ & DD? & 9.19 .10 .0 .0 & 8 Ahau 8 Xul & St. 9 & DD? \\
\hline
\end{tabular}

*AC, accession; AN, anniversary; BL, bloodletting; DD, dedicatory date of monument/architecture; DE, death; PE, period ending (not contemporaneous with monument).

outskirts of modern Copan village. At the main site, Personage $A$ is named on Altar G1 in the main plaza and on the curious stone discovered in Temple $22 \mathrm{~A}$, the probable popol otot. Linda Schele and Nikolai Grube (1987) and I thought that Personage A was probably the half-brother of Ruler 16. As evidence we cited a passage from Altar $U$ that appeared to support this interpretation, although I am now less certain of the decipherment. In Altar U, after the name glyphs of Personage A, a clear reference is made to Ruler 16 's mother, but the intervening glyphs, which we took to be the father's name, are as yet not completely deciphered. The blank spot created by these unread glyphs leads me to extend a caveat concerning the parentage of Personage A. It would seem however, that Personage A's relationship to Ruler 16, whether based on kinship or not, was close.

The most surprising characteristic of Personage $A$ is his use of the Copan emblem glyph title in his name. He is called a $k^{\prime} u l$ ahaw, a title otherwise reserved for the supreme rulers of polities (Stuart 1989). Indeed, when first encountering this name, I initially reasoned that it belonged to a previously unrecognized ruler of Copan, possibly a successor to Ruler 16 . Although such use of the emblem title is perplexing, its presence may lead us to revise our understanding of Copan's political structure near the end of the Late Classic period. The first mention of Personage A comes from a recently discovered incensario lid that records "his seating" on the day 6 Caban $10 \mathrm{Mol}$, surely corresponding to the accession date of Ruler 16 . As with other Copan nobles, it would appear that rulers' accessions were far from individual affairs, involving instead the "seatings" or enthronements of several individuals in office. Unfortunately, we are not told what office or position Personage A took on this important day. Probably he held some political position under the new reign of Ruler 16, the holy lord. Twenty years later, on the anniversary of the accession ceremonies, Personage $\mathrm{A}$ is featured on Altar T. Here an unusual pattern can be seen: Ruler 16 is also named on this stone, but without the expected title "Holy Lord of Copan." Instead, Personage A takes this supreme honorific. The same usage is expressed on the newly discovered stone from Structure 10L-22A (Figure 6). Personage A, named in the ini- 
tial passage, is the holy lord-Ruler 16 , named in the following passage, simply takes a title expressing his age at the time. Ruler 16's name appears in several late inscriptions without the emblem glyph title, which in previous reigns was almost always written alongside the name glyph. He appears prominently in the hieroglyphic record for many years, and in a few texts is called a holy lord (the last date associated with Ruler 16 is 9.19.0.0.0 [A.D. 810], occurring at Quirigua, a pattern that is in itself significant). What are we to make of this evident distinction in title usage? Several explanations are possible, although none can be proved. Was power shared between these two relatives? If so, what was the precise nature of such a joint rule? Why would the supreme title of holy lord be dropped from Ruler 16's name and added to that of Personage A? Is Personage A actually Ruler 17 ?

Such pressing questions are related to a larger issue of the drastically changing political structure of Copan after the death of the fifteenth ruler. When Ruler 16 took office shortly afterwards, he began a program of monumental construction that was markedly different from that of his predecessors. We now know, after reassigning Stela $\mathrm{N}$ to the end of Ruler 15's reign, that Ruler 16 never erected any major stelae at Copan. His inscriptions and monuments are mostly restricted to private settings on the interior of buildings or in the courtyards of the acropolis. Little if any mention is made of this rather reclusive ruler in texts of the Great Plaza or in the court of the Hieroglyphic Stairway. His unusual mode of monument building seems to emphasize his identity as an outsider. I agree with Riese's interpretation that Ruler 16 may have had close famil- ial ties with Quirigua, but specific evidence that he originated from that site is lacking.

Clues about Ruler 16's parentage may eventually provide some much-needed answers about this period. Stela 10's short text indicates that Ruler 16 was the son of a royal woman from Palenque. The identification of his father, however, has remained enigmatic. On the basis of new readings from the inscription found in Structure 10L-22A (Figure 6), we can at least be sure Ruler 16 was not the son of Ruler 15, or Smoke Shell, his predecessor in office. Rather, the text reveals that the father was a previously unknown individual whose political role at Copan is completely unknown. Unfortunately, no potentially revealing titles or honorifics accompany the father's name.

Ruler 16's appearance on the dynastic scene may have involved some drastic political upheavals that are as yet unattested in the epigraphy. In any event, the unusual relationship between Personage A and Ruler 16-we cannot be sure they were brothers, as was previously supposed-may be related to the larger question of the unusual character of Ruler 16's reign. I prefer to leave these ideas as speculations, although we can conclude that Personage $\mathrm{A}$ is one of the most intriguing historical figures of Copan, and no doubt a central player in the changing political landscape of the Late Classic period.

Another figure whose name appears in several late inscriptions was named Yax K'am Lay (this time a readable name) (Table 1). The principal inscriptions that refer to him-Altar $U$, the Structure 10L-22A stone, and several incensario lids-overlap in time with those of Personage $\mathrm{A}$, indicating that the two were contemporaries. The family connections of Yax K'am Lay re-

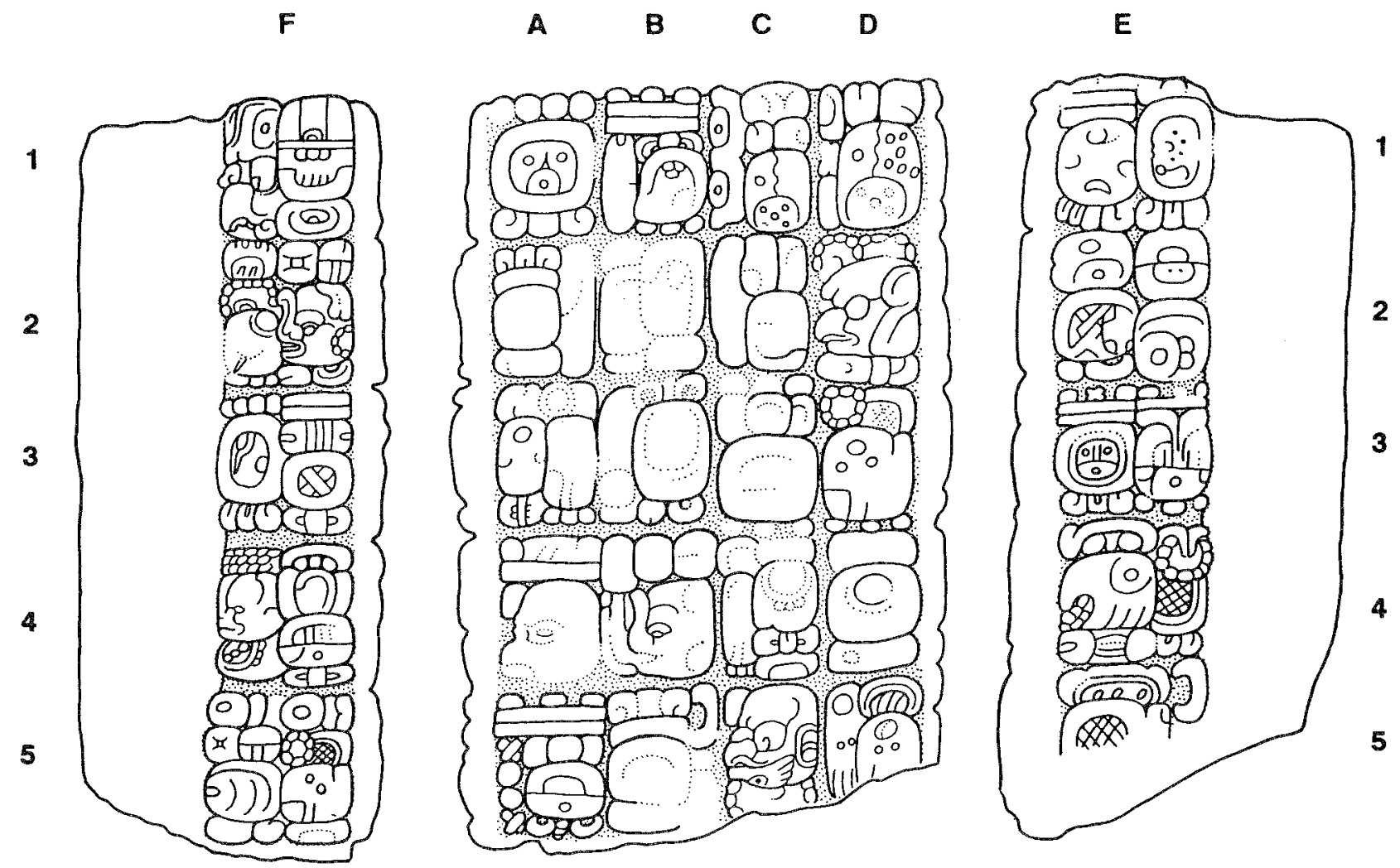

Figure 6. Inscription discovered in Structure 1OL-22A. 
main cloudy, but one glyph accompanying his name on Altar U might well read its'in, "younger brother" (Stuart 1987). This unique reference may link him by blood to Ruler 16, Personage A, or both of these figures.

As with Personage A, references to Yax K'am Lay contain some unusual features. For example, two "seating" dates are associated with him. The first is on the date 9.16.12.5.17 6 Caban $10 \mathrm{Mol}$, well known as the inauguration day of Ruler 16 and, as we have already seen, the "seating" also of Personage A. Two incensario lids and Altar U note another "seating" for Yax K'am Lay on $3 \mathrm{~Eb} 0$ Pop, or 9.17.9.2.12 (A.D. 780). To what do these "seatings" refer? Were two "offices" attained on these different dates? Unfortunately, the prepositional phrases specifying such positions ("in the rulership; in the sahalship") are left out of these texts. Since various offices are known from Maya inscriptions, we must not assume that a "seating" event necessarily implies a ruler's inauguration, nor that several seatings point to patterns of corulership.

Although Yax Kam Lay's political role as younger brother cannot be precisely understood, he does carry a Copan emblem glyph, or what is more precisely his own version of the title. Whereas Ruler 16 and, years later, Personage A are both called $k^{\prime} u l$ ahaws of Copan, Yax Kam Lay is a yax k'ul ahaw, perhaps translatable as "first holy lord." The title is not unique in Maya inscriptions - another occurs on Caracol Stela 3 in the beginning of the Late Classic period, for example. Its meaning at both sites, however, is obscure, yet it might reflect some specific political role or office within the political hierarchy.

Any discussion of subsidiary nobles at Copan surely must include Structure 9N-82, often referred to as the Scribe's Palace or, alternatively, as the House of the Bacabs (Webster 1989). The names given to the structure result from analysis hieroglyphs on an inscribed bench and the exterior mosaic sculptures. Riese (1989) noted, for instance, the presence in the bench's text of a glyph he reads as ahaw k'in, or "calendar priest." Fash's (1989b) analysis of the exterior mosaic sculptures led to the reconstruction of supernatural monkey-scribe figures, and a threedimensional portrait of the same deity was found in association with earlier construction phases. Both textual and symbolic clues therefore led to the functional interpretation of the building as a scribe's palace. Nonetheless, our understanding of the bench inscription has changed since its perceptive analysis by Riese. In the first place, we can confidently date the structure to 9.17.10.11.011 Ahau 3 Ch'en (A.D. 781), which differs from Riese's (1989) placement of 9.17.16.13.10 11 Oc 3 Yax (A.D. 787) (a difference of six years may seem negligible in archaeological terms, but such hieroglyphic details may provide important clues for historical reconstructions). The name of the house owner is clearly indicated in the inscription, as are several poorly understood statements of relationship. Significantly, nowhere in this inscription is the protagonist called a scribe, or $a h t s^{\prime} i b$, nor is he referred to as a calendar priest. The putative ahaw $k$ 'in glyph is actually the name of the protagonist's mother, $N a$ K'in Ahaw. The only glyph that may provide information about his social or political function comes near the end of the text (Figure 7a), where a political relationship with Ruler 16 is specified. The term referring to the bench protagonist is a common title in many Maya inscriptions (Figure 7b). Ringle (1988) has recently offered a translation of the glyph as ah $k^{\prime} u l n a$, "he of the temple." An alternative reading seems possible, however, based on the Yucatec term $a h k^{\prime} u l$, which refers to political mediators between rulers and the people (Martínez Hernández 1929). The ex-

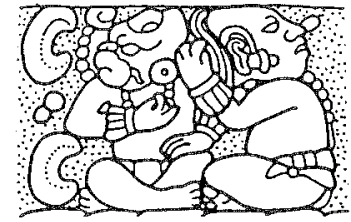

a

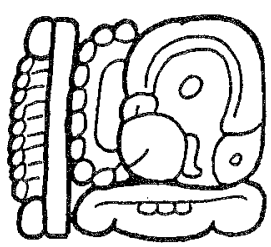

b

Figure 7. Title for subordinates at Copan and elsewhere, perhaps read ah $k^{\prime} u l$ : (a) possessive form ( . . the ah $k^{\prime} u l$ (?) of . . .) on the inscribed bench of Structure $9 \mathrm{~N}-82 ;$ (b) as found in most other inscriptions.

terior scribe figures that flank the doorway of the Scribe's Palace provide much stronger evidence for the functional interpretation, although even here we must be careful.

The same ah $k^{\prime} u l$ title appears on the so-called Harvard Bench from Structure 9M-18. There, the same relationship is expressed between the bench's nonroyal protagonist and Ruler 15 . An unusual feature of this text, however, concerns its probable date. As Linda Schele (1989b) has shown, four of the five possible dates of this bench's dedication fall within the reign of Ruler 16. Indeed, the bench inscription notes Ruler 16's own bloodletting rite on the period ending 9.17.10.0.0 (A.D. 780). If the bench was dedicated within Ruler 16's reign, the subsidiary relationship between the protagonist and Ruler 15 stands out all the more. The political relationship expressed here reveals the personal nature of such alliances, rather than a simple expression of hierarchical relationship between two contemporary political offices. Even during the reign of Ruler 16, the bench protagonist still called himself the $a h k^{\prime} u l$ of the deceased Ruler 15. The $9 \mathrm{M}-18$ bench inscription may help us to understand more precisely the nature of the relationships between subsidiary appointees and their rulers.

Was Ruler 16 the last of the holy lords to reign at Copan? Differing views now exist on the issue. Nikolai Grube and Linda Schele (1987) believe that the unfinished Altar L from Copan's Main Group mentions that accession on 9.19.11.14.15 (A.D. 822) of Ruler 16's successor, named U Kit Tok'. This identification is uncertain, however, since no office is specified with the event, recalling the manner of recording the "seatings" of several subsidiaries at Ruler 16's inauguration. It is equally plausible that U Kit Tok' was a subsidiary noble under Ruler 16 or whomever was in power at that time. ${ }^{8}$ As more subsidiaries are detected

${ }^{8}$ The carving on Copan's Altar L was left unfinished (B. Fash, personal communication 1988), which would seem to support the interpretation that $U$ Kit Tok' may have been the final ruler, interrupted by political collapse. However, monuments at other sites also bear unfinished details or blank glyph blocks. Hieroglyphic Stairway 1 at Dos Pilas is a good example, and, significantly, it was left unfinished by one of the earlier rulers of the local dynasty, Ruler 2 (Houston and Mathews 1985). Copan's Altar L therefore may not be as late as previously believed. 
in Maya inscriptions, we must take greater care in determining the offices and positions they occupied.

\section{COMPARISONS AND CONCLUSIONS}

Epigraphic evidence from Copan would seem to agree with a model seeing an expanding population of the local elite during the Late Classic period. During the Early Classic, the mention of subsidiary nobles and their titles or positions is generally absent from Copan's record. However, this situation is by no means restricted to Copan. At several lowland sites we find a similar gradual rise in the hieroglyphic record of references to lesser nobles (Stuart 1992). At Yaxchilan, Piedras Negras, Palenque, and other western centers, the title sahal (perhaps meaning "feared one," as Michael Coe pointed out to me) appears at the beginning of the Late Classic period and becomes more numerous as the collapse approaches. In some respects, therefore, Copan can be viewed as a reflection of a much wider pattern in Classic Maya political evolution. Throughout the southern Maya Lowlands in the eighth century, historical inscriptions begin to celebrate important individuals who are not rulers nor seemingly members of the royal family. Nobles such as the ah $\mathrm{k}^{\prime}$ uls become suddenly prominent, as do the sahals in the western region, near the Usumacinta River. Is the higher profile of lesser elites a reflection of changing political structures? Or were such political structures always present from an early date but simply emphasized in texts dating soon before the collapse? In either interpretation, we find distinct changes in the concerns of the Maya elite as reflected in the historical record. We may speculate, as many have, that the emergence of subsidiary lords at the end of the Late Classic period indicates an actual spread of the power base away from the exclusive domain of the ruler. If we are to view this as a foreshadowing of political disintegration, the types of subsidiary offices and positions that seem to spring up in the Late Classic inscriptions must be documented as carefully as possible.

Inscribed benches from Copan might suggest that some of the relationships between ruler and subordinate were personal alliances, with one $a h k^{\prime} u l$ noting his connection to a dead ruler rather than to the current office holder. At other Maya sites, subsidiary positions such as the sahal appear to cross-cut individual reigns and thus may be more "institutionalized." However, as Stephen Houston points out (personal communication 1989), the positions of some sahals may still have been intimately tied to rulers. At Piedras Negras and surrounding sites

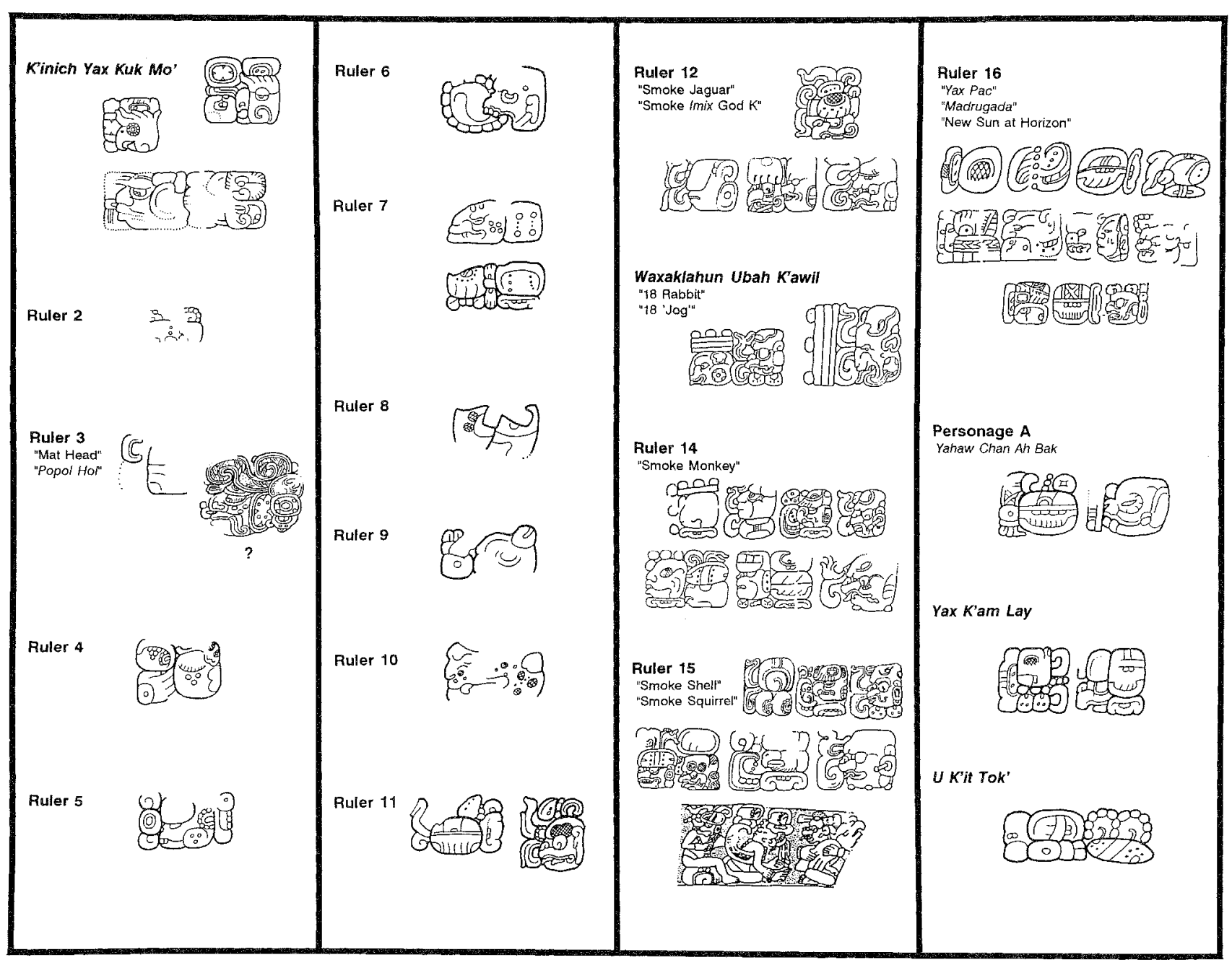

Figure 8. Name glyphs of Copan rulers and other nobles. 
such as El Cayo, "appointed" sahals come to office within a few months of the ruler's accession. Similarly, the mention of sahals at Yaxchilan is most frequent within the first years of a ruler's reign. Once in office, however, subsidiaries at both the Usumacinta sites and Copan apparently held their positions after the death of the ruler who installed them.

At Copan, the question remains whether institutionalized joint rule was developing at the end of the Late Classic period (Schele and Freidel 1990). Royal "brothers" do become prominent, but their actual political roles are frustratingly unclear in the records left to us. The poorly understood relationship between Ruler 16 and Personage A, both called Holy Lords, is especially important in resolving this question. Whatever the precise nature of Copan's political organization at this time, we must view it in the context of similar changes evident in the inscriptions of other Maya sites at the end of the Late Classic period. For the time being, I would hesitate to see the prominence of royal siblings as reflecting the process that ultimately led to the multepal or joint-rule organization of Mayapan and, earlier, Chichen Itza (Schele and Freidel 1990:361), where Bishop
Diego de Landa tells us that three brothers ruled together - a situation supported by the historical information of the Terminal Classic inscriptions (Stuart 1989; Schele and Freidel 1990).

I have tried here to demonstrate the simple point that the study of Maya written history at Copan and elsewhere, when carefully considered, provides a unique understanding of certain cultural processes that shaped the evolution of Maya politics. Processual perspectives on the Classic Maya have been the subjects of many diverse studies in recent years, and the culturehistorical foundations upon which any such models must rely are only now becoming realized through epigraphic research. I hope that this incomplete review of the textual evidence at $\mathrm{Co}$ pan will have shown that epigraphy can easily move beyond the simple description of dynastic sequences and historical events that has now dominated the field for almost three decades. The documents and the historical background they provide, biased as they no doubt are, can be used as sources for addressing farreaching anthropological questions about the rise and eventual collapse of Copan's sociopolitical system.

\section{RESUMEN}

Este ensayo sirve como resumen del trabajo reciente sobre los textos jeroglíficos de Copan, incluyendo un tratamiento detallado de la secuencia dinástica de este sitio durante la época clásico. La discusión se enfoca sobre varios cambios temáticos entre las inscripciones del clásico temprano y del clásico tardío.

La mayoría de los textos del clásico temprano son fragmentários y muy difíciles á leer; por eso, la historia de este época se queda largamente obscura. Sin embargo, hay mucha información esenciál sobre el clásico temprano en los monumentos de subsiguientes épocas, como Altar Q y la escalinata jeroglífica de la Estructura 10L-26. Los datos que tenemos, aunque sean escasos, afirman que estas fuentes tardias no son exageradas en sus recuentos de la historia más antiguo.
Al contrario a los otros sitios mayas, a los textos de Copan, especialmente los más tempranos, les faltan la calidad narrativo de la historia. Cerca del fin del clásico tardio, después de la muerte del Gobernante 13, ó Waxaklahun Ubah K'awil, los textos acercan más la forma narrativa. Los temas de esos textos se tratan de figuras como Gobernante 16 y otras personas de la nobleza. Esos cambjos de tema pueden ser productos de influencias exteriores o cambios políticos poco antes del colapso ca. 850 d.C.

Tratando los hechos sobre estos temas, este ensayo intenta integrar los datos arqueológicos y epigráficos para que otros puedan hacerlo mismo.

\section{ACKNOWLEDGMENTS}

Although I must take responsibility for my ideas, much of my understanding of Copan's inscriptions has come through intensive collaboration with colleagues. At Copan, Linda Schele, Nikolai Grube, and I have enthusiastically discussed and debated various glyph readings and their implications. Many thanks also go to Bridget Hodder Stuart and

\section{REFERENCES}

Ashmore, Wendy

1991 Site-Planning Principles and Concepts of Directionality Among the Ancient Maya. Latin American Antiquity 2(3):199-226.

Aveni, Anthony F.

1980 Skywatchers of Ancient Mexico. University of Texas Press, Austin.

Baudez, Claude F.

1988 Solar Cycle and Dynastic Succession in the Southeast Maya Zone. In The Southeast Classic Maya Zone, edited by Elizabeth $\mathrm{H}$. Boone and Gordon R. Willey, pp. 125-148. Dumbarton Oaks, Washington, DC.

Beetz, Carl P., and Linton Satterthwaite

1981 The Monuments and Inscriptions of Caracol, Belize. University Museum Monographs No. 45. University Museum, University of Pennsylvania, Philadelphia.

Berlin, Hienrich

1958 El glifo "emblema" en las inscripciones mayas. Journal de la Société des Américanistes 47:111-119.
Stephen Houston for their editorial help on this paper, as well as George Stuart for his aid in the illustrations. My first visit to Copan came in 1986, at the invitation of William and Barbara Fash; their continued support, encouragement, and deep friendship can never be adequately acknowledged.

1968 The Tablet of the 96 Glyphs at Palenque, Chiapas, Mexico. In Middle American Research Institute, Tulane University 26:135-149.

Brown, Cecil H.

1991 Hieroglyphic Literacy in Ancient Mayaland: Inferences from Linguistic Data. Current Anthropology 32(4):489-496.

Carlson, John B.

1977 Copan Altar Q: the Maya Astronomical Conference of A.D. 763? In Native American Astronomy, edited by Anthony Aveni, pp. 100-109. University of Texas Press, Austin.

Coe, Michael D.

1976 Early Steps in the Evolution of Maya Writing. In Origins of Religious Art and Iconography in Pre-Classic Mesoamerica, edited by Henry B. Nicholson, pp. 107-122. UCLA Latin American Center and the Ethnic Arts Council of Los Angeles, Los Angeles.

Fash, William L.

1983 Maya State Formation: A Case Study and its Implications. Un- 
published Ph.D. dissertation, Department of Anthropology, Harvard University.

1989a A New Look at Maya Statecraft from Copan, Honduras. Antiquity 62:157-169.

1989b The Sculptural Facade of Structure 9N-82: Content, Form, and Significance. In The House of the Bacabs, Copan, Honduras, edited by David Webster, pp. 41-72. Studies in Pre-Columbian Art and Archaeology No. 29. Dumbarton Oaks, Washington, DC.

1991 Scribes, Warriors and Kings: The City of Copan and the Ancient Maya. Thames and Hudson, New York.

Fash, William L., and Robert J. Sharer

1991 Sociopolitical Developments and Methodological Issues at Copan, Honduras: A Conjunctive Perspective. Latin American Antiquity 2(2): 166-187.

Fash, William L., and David S. Stuart

1991 Dynastic History and Cultural Evolution at Copan, Honduras. In Classic Maya Political History: Hieroglyphic and Archaeological Evidence, edited by T. Patrick Culbert, pp. 147-179. Cambridge University Press, Cambridge.

Fash, William L., Richard V. Williamson, Carlos Rudy Larios, and Joel Palka

1992 The Hieroglyphic Stairway and its Ancestors: Investigations of Copan Structure 10L-26. Ancient Mesoamerica 3:105-115.

Goodman, J.T.

1897 The Archaic Maya Inscriptions. Appendix to Biologia Centrali Americana: Archaeology. Taylor and Francis, London.

Grube, Nikolai

1990 A Reference to Water-lily Jaguar on Caracol Stela 16. Copan Note 68. Unpublished manuscript.

Grube, Nikolai, and Linda Schele

1987 U Cit Tok, the Last King of Copan. Copan Note 21. Unpublished manuscript.

$1988 \mathrm{Cu}-\mathrm{Ix}$, the Fourth Ruler of Copan and his Monuments. Copan Note 40. Unpublished manuscript.

Houston, Stephen D.

1983 A Reading for the Flint-Shield Glyph. In Contributions to Maya Hieroglyphic Decipherment, vol. 1, pp. 13-25. HRAF: New Haven.

1989 Archaeology and Maya Writing. Journal of World Prehistory $3(1): 1-32$.

Houston, Stephen D., and Peter Mathews

1985 The Dynastic Sequence of Dos Pilas, Guatemala. PreColumbian Art Research Institute, Monograph 1. Pre-Columbian Art Research Institute, San Francisco.

Jones, Christopher

1983 New Drawings of Monuments 23 and 24, Quirigua, Guatemala. In Quirigua Reports, no. 2, edited by Robert J. Sharer, Edward M. Shortman and Patricia A. Urban. University Museum Monograph 49. University Museum, University of Pennsylvania, Philadelphia.

Longyear, John

1952 Copan Ceramics: A Study of Southeastern Maya Pottery. Carnegie Institution of Washington, Washington, DC.

Lounsbury, Floyd G.

1989 The Names of a King: Hieroglyphic Variants as a Key to Decipherment. In Word and Image in Maya Culture: Explorations in Language, Writing and Representation, edited by William F. Hanks and Don S. Rice, pp. 73-91. University of Utah Press, Salt Lake City.

Marcus, Joyce

1976 Emblem and State in the Classic Maya Lowlands. Dumbarton Oaks, Washington, DC.

Martínez Hernández, Juan

1929 Diccionario de motul maya-español atribuido a fray Antonio de Ciudad Real y Arte de la lengua maya por Juan Coronel. Talleres de la Compañia Tipográfica Yucateca, Mérida.

Mathews, Peter

1988 The Sculpture of Yaxchilan. Unpublished Ph.D. dissertation, Department of Anthropology, Yale University.

Millar, Fergus

1983 Epigraphy. In Sources for Ancient History, edited by Michael Crawford, pp. 80-136. Cambridge University Press, Cambridge. Miller, Mary E.

1988 The Meaning and Function of the Main Acropolis, Copan. In
The Southeast Classic Maya Zone, edited by Elizabeth H. Boone and Gordon R. Willey, pp. 149-194. Dumbarton Oaks, Washington, DC.

Miller, Mary E., and Stephen D. Houston

1987 The Classic Maya Ballgame and its Architectural Setting: A Study of Relations between Text and Image. Res 14:46-65.

Morley, Sylvanus G.

1920 The Inscriptions at Copan. Carnegie Institution of Washington, Washington, DC.

Orejel, Jorge L.

1990 The "Axe/Comb" Glyph as ch'ak. Research Reports on Ancient Maya Writing No. 31. Center for Maya Research, Washington, DC.

Pendergast, David $\mathrm{M}$

1989 The Products of their Time: Iconography in Social Context. In Cultures in Conflict: Current Archaeological Perspectives, edited by Diana Claire Tkaczuk and Brian C. Vivian, pp. 69-72. Archaeological Association of the University of Calgary, Canada.

Proskouriakoff, Tatiana

1960 Historical Implications of a Pattern of Dates at Piedras Negras, Guatemala. American Antiquity 25:454-475.

1963 Historical Data in the Inscriptions of Yaxchilan, Part I. Estudios de Cultura Maya 3:149-167.

1964 Historical Data in the Inscriptions of Yaxchilan, Part II. Estudios de Cultura Maya 4:177-201.

1973 The Hand-grasping-fish and Associated Glyphs on Classic Maya Monuments. In Mesoamerican Writing Systems, edited by Elizabeth P. Benson, pp. 165-178. Dumbarton Oaks, Washington, DC.

Riese, Berthold

1984 Hel Hieroglyphs. In Phoneticism in Maya Hieroglyphic Writing, edited by John S. Justeson and Lyle Campbell, pp. 263-286. Institute for Mesoamerican Studies Publication No. 9. State University of New York, Albany.

1986 Late Classic Relationship between Copan and Quirigua: Some Epigraphic Evidence. In The Southeast Maya Periphery, edited by Patricia A. Urban and Edward M. Shortman, pp. 94-101. University of Texas Press, Austin.

1988 Epigraphy in the Southeast Zone in Relation to Other Parts of Mesoamerica. In The Southeast Classic Maya Zone, edited by Elizabeth H. Boone and Gordon R. Willey, pp. 67-94. Dumbarton Oaks, Washington, DC.

1989 The Inscription on the Sculptured Bench of the House of the Bacabs. In The House of the Bacabs, edited by David Webster, pp. 82-88. Studies in Pre-Columbian Art and Archaeology No. 29. Dumbarton Oaks, Washington, DC.

Ringle, William M.

1988 Of Mice and Monkeys: The Value and Meaning of T1016, the God C Hieroglyph. Research Reports on Ancient Maya Writing No. 18. Center for Maya Research, Washington, DC.

Sanders, William T.

1989 Household, Lineage, and State in Eighth-Century Copan, Honduras. In The House of the Bacabs, edited by David Webster, pp. 89-105. Studies in Pre-Columbian Art and Archaeology No. 29. Dumbarton Oaks, Washington, DC.

Schele, Linda

1986 Moon-Jaguar, the Tenth Successor of the Yax K'uk' Mo' Lineage. Copan Note 14. Unpublished manuscript.

1989a The Early Classic Dynastic History of Copan. Copan Note 70. Unpublished manuscript.

1989b A House Dedication on the Harvard Bench at Copan. Copan Note 51 . Unpublished manuscript.

1990 Early Quirigua and the Kings of Copan. Copan Note 75. Unpublished manuscript.

Schele, Linda, and David Friedel

1990 A Forest of Kings: The Untold Story of the Ancient Maya. William Morrow, New York.

Schele, Linda, and Nikolai Grube

1987 The Brother of Yax-Pac. Copan Note 20. Unpublished manuscript.

Schele, Linda, and David Stuart

1986 Waterlily-Jaguar, the Seventh Successor of the Lineage of Yax K'uk' Mo'. Copan Note 16. Unpublished manuscript. 
Seler, Eduard

1899 Die Monumente von Copán and Quiriguá und die Altarplatten von Palenque. Zeitschrift für Ethnologie 31:670-738.

1890 Einiges mehr über die Monumente von Copán und Quiriguá. Zeitschrift für Ethnologie 32:188-227.

Sharer, Robert J.

1978 Archaeology and History at Quirigua, Guatemala. Journal of Field Archaeology 5:51-70.

Sharer, Robert J., Julia C. Miller, and Loa P. Traxler

1992 Evolution of Classic Period Architecture in the Eastern Acropolis, Copan: A Progress Report. Ancient Mesoamerica 3:145-159.

Stephens, John Lloyd

1841 Incidents of Travel in Central America, Chiapas and Yucatan. 2 vols. Harper and Brothers, New York.

Stone, Andrea

1983 The Zoomorphs of Quirigua, Guatemala. Ph.D. dissertation, Department of Art History, University of Texas at Austin.

Stuart, David

1987 Ten Phonetic Syllables. Research Reports on Ancient Maya Writing No. 14. Center for Maya Research, Washington, DC.

1992 Historical Inscriptions and the Maya Collapse. To appear in On the Eve of Collapse: The Eighth Century Classic Maya, edited by Jeremy Sabloff and John Henderson. Dumbarton Oaks, Washington, DC.
Stuart, David, and Stephen D. Houston

1991 Classic Maya Place Names. Dumbarton Oaks, Washington, DC, in press.

Stuart, David, and Linda Schele

1986 Interim Report on the Hieroglyphic Stairway of Structure 26. Copan Note 17. Unpublished manuscript.

Taube, Karl

1983 The Teotihuacan Spider Woman. Journal of Latin American Lore 9(2): 107-189.

Trigger, Bruce

1989a A History and Contemporary American Archaeology: A Critical Analysis. In Archaeological Thought in America, edited by C.C. Lamberg-Karlovsky, pp. 19-34. Cambridge University Press, Cambridge.

1989b History of Archaeological Thought. Cambridge University Press, Cambridge.

Webster, David

1989 Introduction to The House of the Bacabs, Copan, Honduras, pp. 1-4. Studies in Pre-Columbian Art and Archaeology No. 29. Dumbarton Oaks, Washington, DC.

Willey, Gordon R., and Richard M. Leventhal

1979 Prehistoric Settlement at Copan. In Maya Archaeology and Ethnohistory, edited by Norman Hammond, pp. 75-102. University of Texas Press, Austin. 